\title{
Hypomagnesemia with Increased Metabolism of Parathyroid Hormone and Reduced Responsiveness to Calcitropic Hormones
}

\author{
Seiko Mori, Shun-ichi Harada, Ryo Okazaki, Daisuke Inoue, Toshio Matsumoto \\ and Etsuro OGata
}

\begin{abstract}
A patient with severe hypomagnesemia due to chronic alcoholism is presented who repeatedly exhibited marked hypocalcemia with a dissociation between radioimmunoassay findings for mid region of parathyroid hormone (PTH-M) and immunoradiometric assay findings of serum intact PTH (PTH-intact). Serum PTH-M was moderately elevated whereas serum PTH-intact was in a low normal range every time when her serum magnesium $(\mathrm{Mg})$ concentration was markedly reduced. There was also a marked reduction in serum osteocalcin concentration. Supplementation of $\mathrm{Mg}$ resulted in a sharp increase in serum PTH level with a rapid disappearance of the dissociation between the two immunoassays of PTH. Shortly after serum $\mathrm{PTH}$ and $1,25(\mathrm{OH})_{2} \mathrm{D}$ levels reached their peak, serum osteocalcin started to increase, and was elevated into a supranormal level with normalization of serum Ca concentration. $\mathrm{Mg}$ is thought to act as a mimic/antagonist of calcium (Ca), and high extracellular $\mathrm{Ca}$ is shown to cause an inhibition of secretion with a stimulation of degradation of PTH. Thus, these observations are consistent with the hypothesis that $\mathrm{Mg}$ deficiency causes an increase in the metabolism of PTH and a reduction in the secretion of bioactive intact PTH by increasing the sensitivity of parathyoiơ cells to $\mathrm{Ca}$. In addition, the fact that hypocalcemia disappeared concomitant with a marked increase of serum osteocalcin from undetectable levels suggest that refractoriness of bone to calcitropic hormones is present which plays a significant role in the development of hypocalcemia under hypomagnesemia, and that serum osteocalcin can be a good marker for the assessment of the responsiveness of bone to calcitropic hormones in these patients.
\end{abstract}

(Internal Medicine 31: 820-824, 1992)

Key words: magnesium deficiency, hypocalcemia, hypoparathyroidism, parathyroid hormone secretion, osteocalcin

\section{Introduction}

Magnesium (Mg) deficiency has been shown to cause functional hypoparathyroidism with hypocalcemia (1). Previous studies demonstrated that serum parathyroid hormone $(\mathrm{PTH})$ concentration is suppressed in patients with hypomagnesemia $(2,3)$. In addition, there has been data to suggest that the responsiveness of adenylate cyclase to PTH is also impaired by $\mathrm{Mg}$ deficiency, and refractoriness to PTH has been postulated (4-6). However, the exact mechanism of functional hypoparathyroidism in $\mathrm{Mg}$ deficiency is as yet unclear partly because of a lack of reliable clinical markers for the assessment of parathyroid function and bone turnover.

Recently, sensitive assays of serum PTH concentratión have been developed. Midregion PTH assay (PTH-M) is a radioimmunoassay using sequence-specific antibodies against midportion of PTH. Because the antibodies recognize inactive carboxyl fragments as well as intact $\mathrm{PTH}$, a major portion of measured PTH-M is inactive fragments which are much more abundant in the serum $(7,8)$. Another is an immunoradiometric assay using antibodies against amino- and carboxy-terminal portion of PTH, which detects only intact molecule of PTH

From the Fourth Department of Internal Medicine, University of Tokyo Faculty of Medicine, Tokyo

Received for publication November 14, 1991; Accepted for publication February 26, 1992

Reprint requests should be addressed to Dr. Toshio Matsumoto, the Fourth Department of Internal Medicine, University of Tokyo Faculty of Medicine, 3-28-6 Mejirodai, Bunkyo-ku, Tokyo 112, Japan 
(PTH-intact) (9). As a marker for the clinical assessment of bone turnover, the measurement of serum osteocalcin concentration has become a useful tool $(10,11)$. In the present study, these parameters were simultaneously measured to assess the secretion and metabolism of PTH as well as responsiveness of bone to PTH in a patient who repeatedly exhibited hypocalcemia due to hypomagnesemia.

\section{Materials and Methods}

Serum and urinary $\mathrm{Ca}$ and $\mathrm{Mg}$ levels were measured by an autoanalyzer (Hitachi model 705 and 736, Tokyo, Japan). Serum PTH-M was determined with a kit using an antibody against human PTH(44-68) (Yamasa Shoyu Co., Choshi, Japan) (12). The detection limit of the assay was $50 \mathrm{ng} / 1$, and intra- and inter-assay coefficiency of variance (CV) were $4.6 \%$ and $8.6 \%$, respectively. Serum PTH-intact was measured by two-site immunoradiometric assay using anti-human $\mathrm{PTH}(1-34)$ and anti-human PTH(39-84) goat antibody (Nichols Institute, CA) (9). Anti-human PTH(39-84) antibody was immobilized onto polystyrene beads, and anti-human PTH(1-34) was radiolabeled with ${ }^{125}$ I. Synthetic human PTH(1-84) was used as a standard. The detection limit of the assay was less than $5 \mathrm{ng} / \mathrm{l}$, and intra- and inter-assay CV's were $5.8 \%$ and $6.0 \%$, respectively. Serum osteocalcin was determined by a radioimmunoassay using antiosteocalcin rabbit antiserum (CIS Inc., France) (11). Detection limit of the assay was $0.25 \mathrm{mg} / \mathrm{l}$, and intraand inter-assay CV's were less than $10 \%$. Serum 25 hydroxyvitamin D [25(OH)D)] was measured by competitive protein assay using vitamin $\mathrm{D}$-deficient rat serum, and serum 1,25-dihydroxyvitamin $\left.\mathrm{D}\left(1,25(\mathrm{OH})_{2} \mathrm{D}\right)\right]$ by radioreceptor assay using Yamasa $1,25(\mathrm{OH})_{2} \mathrm{D}_{3}$ receptor (Yamasa Shoyu Co., Choshi, Japan) as reported previously (13).

\section{Case Report}

A 53-year-old woman was repeatedly admitted to our hospital because of severe diarrhea and appetite loss. The patient had a long history of alcohol intake, and alcoholic liver dysfunction had been noted. Five months before the first admission, diarrhea and appetite loss developed after a large amount of alcoholic ingestion. She kept drinking thereafter, and was admitted to our hospital. She appeared to start drinking soon after the first discharge, and was readmitted to our hospital with similar symptoms two months after discharge.

Her parathyroid function and parameters of $\mathrm{Ca}$ and $\mathrm{Mg}$ metabolism at the initial examination of each admission are listed in Table 1. A marked hypocalcemia and hypomagnesemia were observed with normal renal function. In the face of hypomagnesemia, fractional excretion of $\mathrm{Mg}$ was not suppressed as reported previously (13). In addition, serum PTH-M level was moderately elevated whereas PTH-intact concentration was in the low normal range despite the presence of hypocalcemia on both occasions.

As shown in Fig. 1, restriction of alcohol along with refeeding without any artificial $\mathrm{Mg}$ supplementation resulted in a sharp increase in serum PTH-M and PTHintact levels with disappearance of the dissociation between these two measurements. However, despite the marked increase in both PTH-M and PTH-intact levels on the 5th hospital day, hypocalcemia persisted. Serum $\mathrm{Ca}$ was normalized on the 10th day when serum PTH levels were also normalized. These data suggested that there was a refractoriness to PTH under these circumstances, and that disappearance of the refractoriness caused a normalization of both serum Ca and PTH levels.

In order to test the possibility of refractoriness to PTH at the kidney and bone under hypomagnesemia, serum level of $1,25(\mathrm{OH})_{2} \mathrm{D}$ and osteocalcin were simultaneously followed at the second admission. As shown in Fig. 2, serum $1,25(\mathrm{OH})_{2} \mathrm{D}$ level was normal on admission, whereas serum osteocalcin concentration was markedly reduced despite the normal serum $1,25(\mathrm{OH})_{2} \mathrm{D}$ concentration. Serum $25(\mathrm{OH}) \mathrm{D}$ concentration was normal $(27 \mathrm{nmol} / \mathrm{l})$. The patient was again followed with the ingestion of regular meal without any artificial supplementation of $\mathrm{Mg}$. Six days after admission, there was only a slight increase in serum $\mathrm{Ca}$ and $\mathrm{Mg}$ levels. However, as observed at the first admission, both PTH-M and PTH-intact started to increase, and the dissociation between them disappeared. Serum creatinine concentration and glomerular filtration rate were unchanged

Table 1. Serum Levels of $\mathrm{Ca}, \mathrm{Mg}$, Creatinine, PTH-M and PTH-intact at First and Second Admissions

\begin{tabular}{lccccccc}
\hline & $\begin{array}{c}\text { Serum Ca } \\
(\mathrm{mmol} / \mathrm{l})\end{array}$ & $\begin{array}{c}\text { Serum Pi } \\
(\mathrm{mmol} / \mathrm{l})\end{array}$ & $\begin{array}{c}\text { Serum Mg } \\
(\mathrm{mmol} / \mathrm{l})\end{array}$ & $\begin{array}{c}\mathrm{FE}_{\mathrm{Mg}} \\
(\%)\end{array}$ & $\begin{array}{c}\text { Serum Cr } \\
(\mu \mathrm{mol} / \mathrm{l})\end{array}$ & $\begin{array}{c}\text { PTH-M } \\
(\mathrm{ng} / \mathrm{l})\end{array}$ & $\begin{array}{c}\text { PTH-intact } \\
(\mathrm{ng} / \mathrm{l})\end{array}$ \\
\hline $\begin{array}{l}\text { First } \\
\quad \text { admission }\end{array}$ & 1.97 & 1.52 & 0.41 & 5.2 & 90 & 760 & 36 \\
$\begin{array}{l}\text { Second } \\
\quad\end{array}$ & & & & & & & \\
$\quad$ admission & 1.47 & 1.13 & 0.41 & 4.8 & 90 & 910 & 21 \\
$\begin{array}{l}\text { Normal } \\
\text { range }\end{array}$ & 2.20 & 0.80 & 0.70 & 3.5 & 50 & 180 & 13 \\
\hline
\end{tabular}




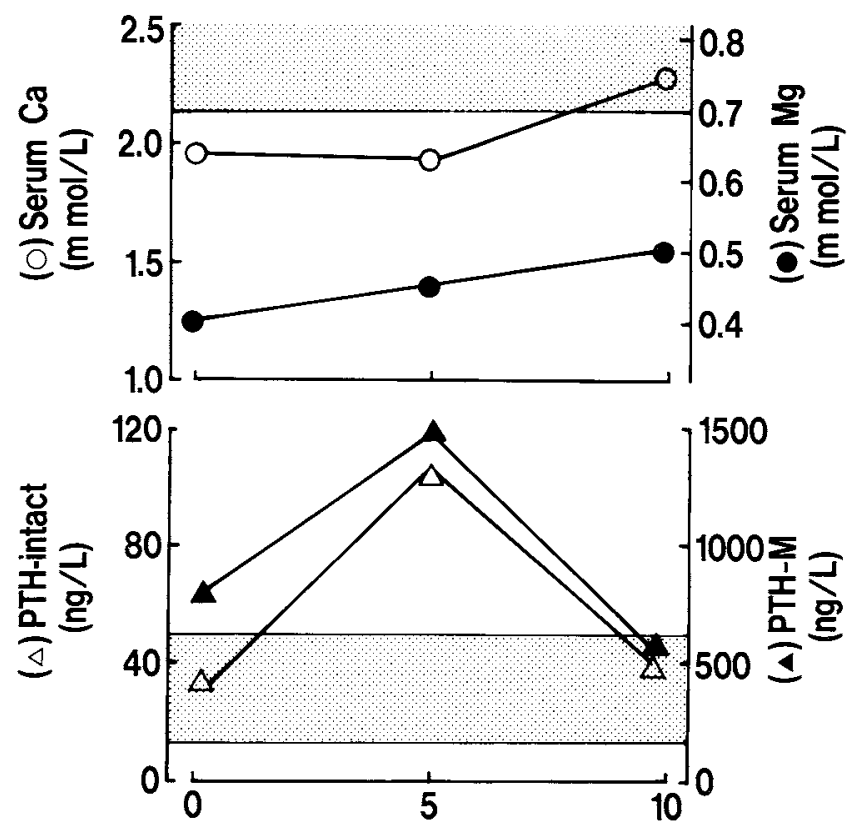

Days after admission

Fig. 1. Clinical course of parathyroid function and parameters of $\mathrm{Ca}$ and $\mathrm{Mg}$ metabolism at the first admission. After admission, alcohol intake was discontinued, and the patient was given a regular meal without any artificial supplementation. The shaded arcas represent normal ranges.

throughout the second admission, and serum BUN was even lower at the admission $(4.6 \mu \mathrm{mol} / 1)$ compared to that on the 6th hospital day $(6.8 \mu \mathrm{mol} / \mathrm{l})$. Serum PTH levels reached their peak on the 10th day when $1,25(\mathrm{OH})_{2} \mathrm{D}$ also rose sharply to a maximal level of $219 \mathrm{pmol} / 1$. These observations were in contrast with those of Rude et al (14) in hypomagnesemic patients showing reduced serum $1,25(\mathrm{OH})_{2} \mathrm{D}$ concentrations which may remain low one to two weeks after $\mathrm{Mg}$ administration, and suggested that the kidney responded normally to PTH in enhancing the production of $1,25(\mathrm{OH})_{2} \mathrm{D}$ in this patient. Although PTH and $1,25(\mathrm{OH})_{2} \mathrm{D}$ were above the upper limit, serum Ca was still low and osteocalcin was undetectable. Serum $\mathrm{Ca}$ and osteocalcin gradually increased and were normalized on the 14th day of admission, when PTH and $1,25(\mathrm{OH})_{2} \mathrm{D}$ fell into near normal range. Four weeks after admission, serum $\mathrm{Mg}$ concentration rose to $0.66 \mathrm{mmol} / \mathrm{l}$ and all the other parameters became normalized except that serum osteocalcin was elevated to far beyond the normal range.

\section{Discussion}

PTH secretion is known to be affected by extracellular Mg. In vitro studies have demonstrated that high extracellular $\mathrm{Mg}$ reduces and low extracellular $\mathrm{Mg}$ enhances PTH secretion from parathyroid cells (14). In contrast, not only an elevation (15) but also a reduction in serum
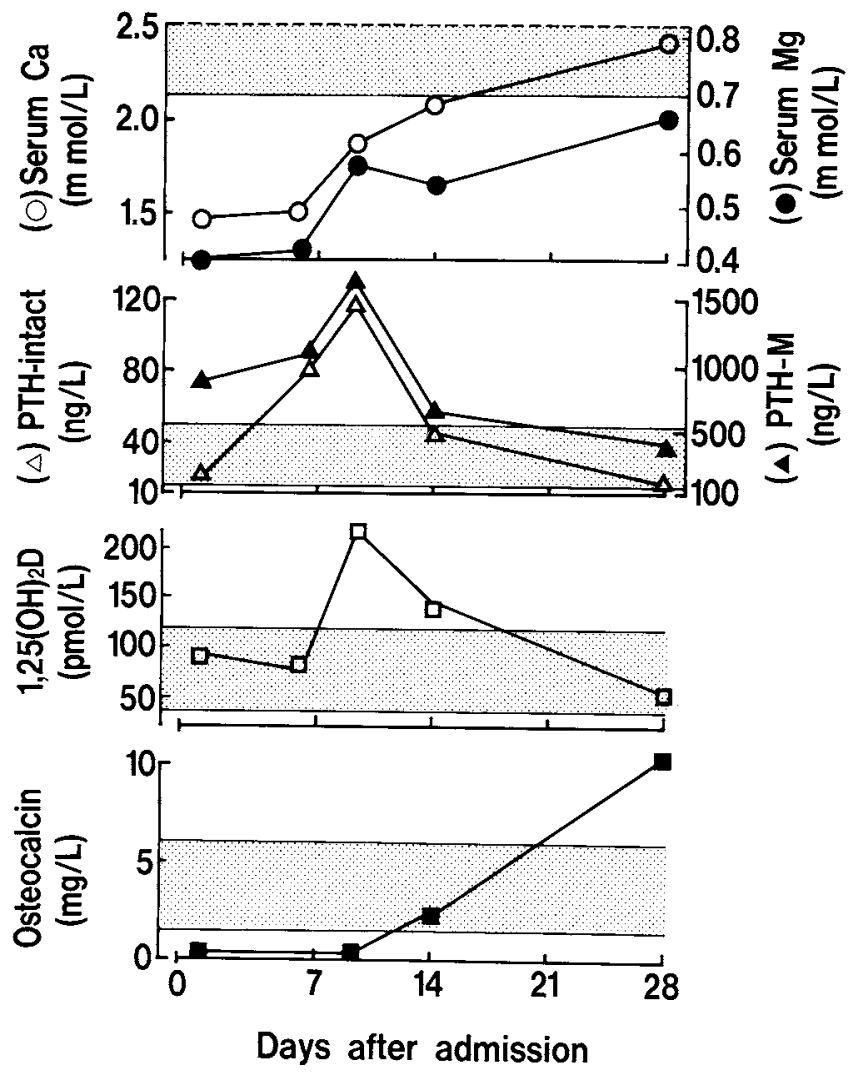

Fig. 2. Clinical course of serum Ca, Mg. PTH-M, PTH-intact, $1,25(\mathrm{OH})_{2} \mathrm{D}$ and osteocalcin concentration at the sccond admission. The patient was followed with refeeding without any artificial $\mathrm{Mg}$ supplementation as in Fig. 1. The shaded areas represent normal ranges.

$\mathrm{Mg}$ concentration suppresses serum PTH levels in humans $(16,17)$, and impaired secretion of PTH has been thought to be one of the major mechanisms of the development of hypocalcemia in Mg deficiency. However, in most of those previous clinical studies, the reliability of radioimmunoassays was controversial due to the poor sensitivity and specificity of the antibodies used (18). In the present study, two sensitive assays of PTH (PTH-M recognizes inactive midregion and $\mathrm{PTH}$-intact detects only bioactive intact molecule of PTH) were simultaneously performed in a patient who repeatedly exhibited hypomagnesemia. It was found that serum PTH-intact was in a low normal range which was inappropriately low for the reduced serum $\mathrm{Ca}$ concentration, whereas the serum PTH-M concentration was moderately elevated on two independent occasions with marked hypomagnesemia. Consistent with these observation, Allgrove et al (19) reported that there is a dissociation between serum PTH concentrations using amino-terminal (PTH$\mathrm{N})$ and carboxy-terminal (PTH-C) specific antibodies, and that PTH-C is elevated in all patients with hypomagnesemia whereas PTH-N is reduced in patients with marked hypomagnesemia. The present observations confirmed those previous results by using much more 
sensitive immunoassays, and demonstrated that the serum levels of bioactive intact PTH decrease and the proportion of inactive carboxyl fragments increase under hypomagnesemia. A similar dissociation between serum PTH-M and PTH-intact concentration has been noted in hypercalcemic patients with primary hyperparathyroidism (18). In those patients, the elevation in serum PTH-M is more pronounced than the PTH-intact concentration, and PTH-M is thought to be a better clinical tool for the diagnosis of primary hyperparathyroidism (18). Thus, in both of these circumstances, there is a possibility that the proportions of inactive carboxyl fragments increases because of an enhanced metabolism of PTH. Although the dissociation between PTH-M and PTH-intact is also commonly observed by an impairment in renal function, the serum creatinine concentration in this patient did not alter throughout the course, and the BUN/creatinine ratio was even lower at the admission when there was a dissociation between serum PTH-M and PTH-intact concentration.

Elevation in the serum Ca concentration has been shown to inhibit the synthesis and stimulate the metabolism of PTH in parathyroid cells $(20-22)$. Increasing evidence favors the view that these effects of extracellular $\mathrm{Ca}$ are mediated through the interaction with a putative plasma membrane "Ca receptor", which provokes an increase in intracellular $\mathrm{Ca}$ concentration through transmembrane signal transduction system (23) to cause an inhibition of PTH secretion (24). High serum Ca concentration is also shown to accelerate the hepatic and renal degradation of PTH (25). Mg appears to compete with $\mathrm{Ca}$ for these $\mathrm{Ca}$ receptors causing a rise in intracellular $\mathrm{Ca}$ concentration, but much higher concentration of $\mathrm{Mg}$ are necessary to induce a similar response (23). Thus, $\mathrm{Mg}$ may at as a mimic/antagonist of $\mathrm{Ca}(26)$. In fact, Mahaffee et al (27) reported an in vitro study using rat parathyroid cells showing that deletion of $\mathrm{Mg}$ from the medium caused a reduction in PTH release at a constant $\mathrm{Ca}$ concentration, and that PTH secretion was enhanced by increasing the $\mathrm{Mg}$ concentration up to $2 \mathrm{mM}$ with a constant $\mathrm{Ca}$ level in the medium. These results are in good agreement with the present clinical observations, and are consistent with the assumption that hypomagnesemia reduces the competitive inhibition by $\mathrm{Mg}$ of the binding of $\mathrm{Ca}$ to its receptors, and that parathyroid and possibly other cells may respond to serum $\mathrm{Ca}$ with much higher sensitivity under hypomagnesemia. As a result, a reduction in PTH secretion associated with an enhancement of PTH degradation in the face of normal or even low serum $\mathrm{Ca}$ ensues by hypomagnesemia.

Another proposed mechanism for the development of hypocalcemia in $\mathrm{Mg}$ deficiency is a refractoriness of target tissues to PTH (4). It has been reported that the response of cyclic AMP to PTH is reduced in kidney and bone by $\mathrm{Mg}$ deficiency $(3,5,6)$. In addition, a decrease in extracellular $\mathrm{Mg}$ concentration causes an impairment of the skeletal response to PTH and $1,25(\mathrm{OH})_{2} \mathrm{D}_{3}$ in organ cultures of fetal rat long bones (28). Graber and Schulman (29) reported that serum Ca did not increase despite the administration of $1,25(\mathrm{OH})_{2} \mathrm{D}_{3}$ unless $\mathrm{Mg}$ was supplemented in a hypomagnesemic patient with postsurgical hypoparathyroidism. However, none of the previous clinical studies have presented convincing evidence to suggest that the skeletal response to calcitropic hormones is in fact impaired in patients with hypomagnesemia. In the present patient, the serum osteocalcin concentration was below the detection limit during $\mathrm{Mg}$ deficiency, and remained low even when serum PTH and $1,25(\mathrm{OH})_{2} \mathrm{D}_{3}$ were markedly elevated. Because osteocalcin is present exclusively in bone and has been shown to closely reflect bone turnover (30), these results support the previous assumption that the responsiveness of bone to calcitropic hormones is suppressed by hypomagnesemia. In addition, the fact that serum Ca concentration normalized after the elevation of serum osteocalcin to a supranormal level suggests that the refractoriness of bone to these hormones plays a significant role in the development of hypocalcemia in patients with $\mathrm{Mg}$ deficiency.

In conclusion, the present study demonstrates that there was a dissociation between serum PTH-M and PTH-intact concentration in a patient with hypomagnesemia, and that supplementation of $\mathrm{Mg}$ resulted in a rapid disappearance of the dissociation between these two measurements with a sharp increase in their serum concentration. These results are consistent with the hypothesis that $\mathrm{Mg}$ deficiency causes an increase in the degradation of $\mathrm{PTH}$ and a reduction in the secretion of bioactive intact PTH by increasing the sensitivity of parathyoid cells to $\mathrm{Ca}$. In addition, the fact that hypocalcemia disappeared concomitant with a marked increase in serum osteocalcin concentration after $\mathrm{Mg}$ supplementation from undetectable levels suggests that the refractoriness of bone to calcitropic hormones is present under hypomagnesemia, and that the serum osteocalcin concentration can be a good marker for the assessment of the responsiveness of bone to these hormones in patients with hypomagnesemic hypocalcemia.

Acknowledgments: This study was supported in part by Grants-inAid for Scientific Research from the Ministry of Education, Science and Culture, and by a Grant for Investigation Committee on Abnormalities in Hormone Receptor Mechanisms from the Ministry of Health and Welfare of Japan.

\section{References}

1) Wacker WEC, Paris AF. Magnesium metabolism. N Engl J Med 278: 658, 712, 772, 1968.

2) Anast CS, Winnacker JL, Fortc LR, Burns TW. Impaired release of parathyroid hormone in magnesium deficiency. J Clin Endocrinol Metab 42: 707, 1976.

3) Rude RK, Oldham SB, Singer FR. Functional hypoparathyroid- 


\section{Mori et al}

ism and parathyroid hormone end-organ resistance in human magnesium deficiency. Clin Endocrinol(Oxf) 5: 209, 1976.

4) Estep H, Shaw WA, Waltington C, Hobe R, Holland W, Tucker $\mathrm{StG}$. Hypocalcemia due to hypomagnesemia, and reversible parathyroid hormone unresponsiveness. J Clin Endocrinol Metab 29: 842, 1969.

5) Freitag J, Martin $K$, Conrades $M$, et al. Evidence for skeletal resistance to parathyroid hormone in magneisum deficiency. $J$ Clin Invest 64: 1238, 1979.

6) Forbes RM, Parker H. Effect of magnesium deficiency on rat bone and kidney sensitivity to parathyroid hormone. J Nutr 110: $1610,1980$.

7) Mallette LE, Tuma SN, Berger E, Kirkland JL. Radioimmunoassay for the middle region of human parathyroid hormone using an homologous antiserum with a carboxy-terminal fragment of bovime parathyroid hormone as radioligand. J Clin Endocrinol Metab 54: 1017, 1982.

8) Marx SJ, Sharp ME, Krudy A, et al. Radioimmunoassay for the middle region of human parathyroid hormone: Studies with a radioiodinated synthetic peptide. J Clin Endocrinol Metab 53: 76, 1981.

9) Okazaki R, Matsumoto T, Furukawa $Y$, et al. Serum intact parathyroid hormone concentration measured by a two-site immunoradiometric assay in normal subjects and patients with various parathyroid disorders. Endocrinol Japan 39: 115, 1992.

10) Epstein S. Serum and urinary markers of bone remodeling: Assessment of bone turnover. Endocr Rev 9: 437, 1988.

11) Delmas PD, Demiaux B, Malaval L, Chapuy MC, Edouard C, Meunier PJ. Serum bone gamma carboxyglutamic acid containing protein in primary hyperparathyroidism and in malignant hypercalcemia. J Clin Invest 77: 985, 1986.

12) Fukase $M$, Fujita $T$, Matsumoto $T$, et al. Clinical studies using a highly sensitive radioimmunoassay for mid-region and carboxy terminus of parathyroid hormone in normal, hypo- and hypercalcemic states. Folia Endocrinol (Jpn) 65: 807, 1989 (in Japanese).

13) Fukumono S, Matsumoto $T$, Tanaka $Y$, Harada S, Ogata E. Renal magnesium wasting in a patient with short bowel syndrome with magnesium deficiency: Effect of $1 \alpha$-hydroxyvitamin $D_{3}$ treatment. J Clin Endocrinol Metab 65: 1301, 1987.

14) Rude RK, Adams JS, Ryzen E, ct al. Low serum concentrations of 1,25-dihdroxyvitamin $\mathbf{D}$ in human magnesium deficiency. $J$ Clin Endocrinol Metab 61: 933, 1985.

15) Habener JF, Potts JT Jr. Relative effectiveness of magnesium and calcium on secretion and biosynthesis of parathyroid hormone in vitro. Endocrinology 98: 197, 1976.

16) Cholst IN, Steinberg SF, Tropper PJ, Fox HE, Segre GV, Bilezikian JP. The influence of hypermagnesemia on serum calcium and parathyroid hormone levels in human subjects. N Engl J Med
310: 1221,1984

17) Rude RK, Oldham SB, Sharp CF Jr, Singer FR. Parathyroid hormone secretion in magnesium deficiency. I Clin Endocrinol Metab 47: 800, 1987.

18) Endres DB, Villaneva R, Sharp CF Jr, Singer FR. Measurement of parathyroid hormone. Endocrinol Metab Clin North Am 18: $611,1989$.

19) Allgrove J, Adami S, Fraher L, Reuben A, O'Riordan JLH. Hypomagnesemia: Studies of parathyroid hormone secretion and function. Clin Endocrinol (Oxf) 21: 435, 1984.

20) Brown EM. PTH secretion in vivo and in vitro. Regulation by calcium and other secretagogues. Mineral Electrolyte Metab 8: 130,1982

21) Mayer GP, Keaton JA, Hurst JC, Habener JF. Effects of plasma calcium concentration on the relative proportion of hormone and carboxyl fragments in parathyroid venous blood. Endocrinology 104: 1778, 1979.

22) Yamamoto $M$, Igarashi $T$, Muramatsu $M$, Fukagawa $M$, Motokura T, Ogata E. Hypocalcemia increases and hypercalcemia decreases the steady-state level of parathyroid hormone messenger RNA in the rat. J Clin Invest 83: 1053, 1989.

23) Nemeth EF, Scarpa A. Rapid mobilization of cellular $\mathrm{Ca}^{2+}$ in bovine parathyroid cells evoked by extracellular divalent cations. Evidence for a cell surface calcium receptor. J Biol Chem 262: $5188,1987$.

24) Shoback DM, Membreno LA, McGhee JG. High calcium and other divalent cations increase inositol triphosphate in bovine parathyroid cells. Endocrinology 123: 382, 1988.

25) Daugaard H, Egfjord M, Olgaard K. Influence of calcium on the metabolism of intact parathyroid hormone by isolated perfused rat kidney and liver. Endocrinology 126: 1813, 1990.

26) Levine BS, Coburn JW. Magnesium, the mimic/antagonist of calcium (Editorial). N Engl J Med 310: 1253, 1984.

27) Mahaffee DD, Cooper CW, Ramp WK, Ontjes DA. Magnesium promotes both parathyroid hormone secretion and adenosine $3^{\prime}$, $5^{\prime}$-monophosphate production in rat parathyroid tissues and reverses the inhibitory effects of calcium on adenylate cyclase. Endocrinology 110: 487, 1982.

28) Johannesson AJ, Raisz LG. Effects of low medium magnesium concentration on bone resorption in response to parathyroid hormone and 1,25-dihydroxyvitamin D in organ culture. Endocrinology 113: 2294, 1983.

29) Graber ML, Schulman G. Hypomagnesemic hypocalcemia independent of parathyroid hormone. Ann Intern Med 104: 804, 1986.

30) Price P. Non collagenous proteins of hard tissuc. in: Bone and Mineral Research, Annual 1, Peck WA, Ed., Excerpta Medica, Amsterdam, 1983, p.157. 